\title{
Plasma progesterone and luteinizing hormone concentrations and the role of the corpus luteum and LH gonadotrophs in the control of delayed implantation in Schreibers' long-fingered bat (Miniopterus schreibersii)
}

\author{
R. T. F. Bernard ${ }^{1}$, C. Bojarski ${ }^{1}$ and R. P. Millar ${ }^{2}$ \\ ${ }^{1}$ Department of Zoology \& Entomology, Rhodes University, Grahamstown 6140, South Africa; and \\ ${ }^{2} M R C$ Regulatory Peptides Research Unit, Department of Chemical Pathology, University of \\ Cape Town, Medical School, Observatory 7925, South Africa
}

\begin{abstract}
Summary. In Schreibers' long-fingered bat from South Africa $\left(\sim 33^{\circ} \mathrm{S}\right)$ copulation, ovulation and fertilization occurred in April and May, implantation was delayed until August, and parturition occurred in December. Delayed implantation coincided with winter, during which the bats remained active, only entering prolonged periods of torpor during particularly cold spells. Plasma progesterone concentration was low during non-pregnancy $(1.54 \mathrm{ng} / \mathrm{ml})$ and during delayed implantation $(1.67 \mathrm{ng} / \mathrm{ml})$, and thereafter increased to reach a peak mean of $64.82 \mathrm{ng} / \mathrm{ml}$ in late pregnancy. Changes in size and ultrastructure of the luteal cells indicated periods of steroidogenesis just after formation of the corpus luteum, and for about 2 months after implantation; reduced steroidogenic activity during delayed implantation; and luteolysis in the last 2 months of pregnancy. Plasma luteinizing hormone $(\mathrm{LH})$ concentration and pituitary LH- $\beta$ immunoreactivity were highest during follicular development and peaked just before ovulation. During early delayed implantation, plasma LH concentration was low, and both plasma LH and pituitary LH- $\beta$ immunoreactivity increased from July, reaching peaks in late pregnancy. LH may be required to activate the corpus luteum and terminate delayed implantation, or, as in some small carnivores, it may be required for luteal maintenance.
\end{abstract}

Keywords: plasma progesterone; plasma luteinizing hormone; luteal activity; gonadotroph activity; bat (Miniopterus schreibersii)

\section{Introduction}

Two fundamentally different reproductive cycles have been described for female long-fingered bats (M. schreibersii) from temperate latitudes. In Japan $\left(33^{\circ} \mathrm{N}\right.$; Kimura \& Uchida, 1983) and Australia $\left(37^{\circ} \mathrm{S}\right.$; Crichton et al., 1989) 2 months of delayed implantation, with implantation occurring in winter, is followed by a period of delayed embryonic development. Normal embryogenesis resumes once the bats arouse at the end of hibernation. By contrast, in the same species from Africa (25-33 ${ }^{\circ}$; ; van der Merwe, 1979; Bernard, 1980; 1989) and France $\left(45^{\circ} \mathrm{N}\right.$; Courrier, 1927) the period of delayed implantation is longer (4-5 months), implantation occurs at or near the end of winter, and there is no period of delayed embryonic development. Obligate delayed implantation, while never common, occurs in many mammalian orders (Renfree \& Calaby, 1981). Within the Chiroptera it is characteristic of the long-fingered bats of the genus Miniopterus from temperate latitudes (Racey, 1982 for review), and has been reported in the horseshoe bat (Rhinolophus rouxi; Ramakrishna \& Rao, 1977) and the fruit bat (Eidolon helvum; Mutere, 1967). 
The hormonal control of delayed implantation is best understood in small carnivores where luteal inactivity and low plasma progesterone concentrations during delayed implantation are controlled through the influence of photoperiod on the production of prolactin (Berria et al., 1989; Sundqvist et al., 1989). Data regarding plasma progesterone concentrations during delayed implantation in long-fingered bats are contradictory. Concentrations are low throughout developmental delay in long-fingered bats from Japan and Australia (Kimura et al., 1987; Crichton et al., 1989), but are significantly increased during delayed implantation in South Africa (van der Merwe \& van Aarde, 1989). Ultrastructural studies of the corpus luteum of long-fingered bats from Japan and Australia (Kimura \& Uchida, 1983; Uchida et al., 1984; Crichton et al., 1989) indicate that the corpus luteum is inactive or suboptimally active throughout developmental delay.

In this paper we describe the monthly changes in concentrations of plasma progesterone and luteinizing hormone, and the ultrastructure and deduced secretory activity of the luteal cells and the LH gonadotrophs of Schreibers' long-fingered bat. Results are compared with those for longfingered bats from Japan and Australia, in which delayed implantation and delayed development occur, and with those previously reported for the same species from South Africa.

\title{
Materials and Methods
}

\begin{abstract}
Animals. Each month 2-3 adult female Schreibers' long-fingered bats (Miniopterus schreibersii) were collected from a set of disused mine tunnels in the East Cape region of South Africa $\left(33^{\circ} 58^{\prime} \mathrm{S}, 25^{\circ} 17^{\prime} \mathrm{E}\right)$. Winters in the study area (May to August/September) are cool and dry, and summers are warm to hot and wet or dry. Bats with a body mass $>9.0 \mathrm{~g}$, a forearm longer than $45 \mathrm{~mm}$ and with blunted teeth were assumed to be adult. Where possible, specimens with large pectoral nipples (indicating a previous pregnancy) were used. Material collected between January 1986 and April 1987 was used for the plasma progesterone assay and for the ultrastructural study of luteal cells; specimens collected in 1988 were used in the immunocytochemical study of the anterior pituitary.
\end{abstract}

Standard light microscopy. Specimens were killed by asphyxiation with $\mathrm{CO}_{2}$ and the female reproductive tract was removed and, excluding the left ovary, was fixed in buffered neutral formalin, embedded in Paraplast, sectioned at $5 \mu \mathrm{m}$, and stained with Ehrlich's haematoxylin and eosin.

Standard electron microscopy. Small $\left(0.1-0.2 \mathrm{~mm}^{3}\right)$ pieces of the left ovary were fixed by immersion in $2.5 \%$ glutaraldehyde in $0.1 \mathrm{~m}$ phosphate buffer (pH 7.3) for $4 \mathrm{~h}$, washed in the buffer and secondarily fixed in $1 \%$ osmium tetroxide for $90 \mathrm{~min}$. After rapid dehydration, the tissues were embedded in resin (Cross, 1989). Ultrathin sections were stained with $5 \%$ aqueous uranyl acetate and lead citrate and examined using a Jeol JEM 100CXII transmission electron microscope.

Recent literature on the ultrastructure of steroidogenic cells has indicated that fixation may be either by perfusion (Crichton et al., 1989) or by immersion (Chegini \& Rao, 1988), but that immersion fixation may cause dilation of the smooth endoplasmic reticulum (Crombie et al., 1971; Crichton et al., 1989) and thus introduce errors into analyses of organelle abundance. Since about $40 \%$ of the luteal cells had vesicular smooth endoplasmic reticulum, this organelle has been omitted from the morphometric analyses.

Immunocytochemistry. Specimens were decapitated and, to ensure rapid fixation of the pituitary gland, fixative was injected into the brain through the foramen magnum. For light microscopy, the pituitary glands were fixed by immersion in $10 \%$ phosphate-buffered $(\mathrm{pH} 7 \cdot 3)$ formalin for $2 \mathrm{~h}$, dehydrated and embedded in paraffin wax (solidification point $46-48^{\circ} \mathrm{C}$ ) at $57^{\circ} \mathrm{C}$. Sections were cut at $5 \mu \mathrm{m}$ and stained with a monoclonal bovine LH- $\beta$ antibody (dilution 1/200; Serotec, Kidlington, Oxford, UK), an IgG-conjugated $1 \mathrm{~nm}$ colloidal gold probe (dilution 1/40; Janssen, Làmmerdines, Olen, Belgium) and silver enhancement (IntenSEM; Janssen). For electron microscopy, the pars nervosa and pars intermedia were discarded, and the remaining pars distalis was fixed by immersion in $0.1 \%$ glutaraldehyde and $3 \%$ formaldehyde for $2 \mathrm{~h}$. The tissue was then dehydrated, embedded in resin (Cross, 1989) and the blocks were polymerized at $37^{\circ} \mathrm{C}$ for 10 days. Ultrathin sections were stained using a monoclonal bovine LH- $\beta$ antibody (dilution 1/400; Serotec) and an IgG-conjugated $20 \mathrm{~nm}$ colloidal gold probe (dilution 1/40; Janssen). The sections were counterstained with $2 \%$ methanolic uranyl acetate, and viewed with a Jeol JEM 100CXII transmission electron microscope. Control and specificity tests, using ovine LH kindly donated by the National Hormone and Pituitary Programme (Baltimore, MD, USA), were performed using standard procedures.

Quantification. All measurements of area were made using a digitizer tablet and SigmaScan software (Jandel Scientific, Corte Madera, CA, USA).

The abundance (volume densities) of luteal mitochondria, lipid droplets and electron-dense, membrane-bound granules was calculated using the point count method of Weibel \& Bolender (1973). A grid, containing 99 squares, each $9 \mathrm{~mm}^{2}$, was drawn on the screen of the electron microscope onto which the image of the tissue was superimposed. 
Ten luteal cells, chosen at random from 2-4 specimens/month, were selected at low power $(\times 4200)$ and the area of cytoplasm that appeared after the magnification had been increased to $\times 19000$ was used for the calculations of abundance (Crichton et al., 1989). Volume density does not take into account changes in the size of the luteal cells and, to obtain a value that is relative to cytoplasmic volume, relative volume densities were calculated (Crichton $e t a l$, 1989).

The abundance of LH gonadotrophs was estimated from one mid-sagittal, immunogold-stained, light-microscope section of the pituitary gland of individual specimens from January, April, May, June and August to October. The surface areas of the pars distalis, in midsagittal section, and the positively stained gonadotrophs were measured, and the area occupied by LH gonadotrophs was expressed as a percentage of the total area. The volume density of positively stained secretory granules in the cytoplasm of $10 \mathrm{LH}$ gonadotrophs from each pituitary was estimated using the point count technique previously described. The numbers of gold particles on 25 granules in $10 \mathrm{LH}$ gonadotrophs were counted for each pituitary gland during the year. A measure of pituitary LH- $\beta$ immunoreactivity was obtained by multiplying the volume density of secretory granules by the number of gold particles per granule (modified after Posthuma et al., 1987).

Progesterone and $\mathbf{L H}$ assays. Blood $(\sim 300 \mu \mathrm{l})$ was collected from the ventricles immediately after specimens were killed. Samples were centrifuged at $1600 \mathrm{~g}$ for $5 \mathrm{~min}$ and plasma (about $150 \mu \mathrm{l}$ ) was stored at $-20^{\circ} \mathrm{C}$ until assayed. $0.1 \mathrm{ml}$ of plasma was extracted with $5.0 \mathrm{ml}$ petroleum ether (40-60), evaporated to dryness, and reconstituted in $0.8 \mathrm{ml}$ benzene of which $0.1 \mathrm{ml}$ aliquots were transferred to borosilicate glass tubes and dried down; $0.1 \mathrm{ml}$ of radioimmunoassay buffer was added with $0.1 \mathrm{ml}$ of progesterone antiserum 1521 (progesterone-21-bovine serum albumen conjugate; titre 1:20000 final; cross-reactions were 11 $\beta$-hydroxyprogesterone (53\%), 11 $\alpha$-hydroxyprogesterone $(25 \%)$, 5 pregnane-3-20-one (22\%), 17ß-hydroxyprogesterone $(3 \%)$, pregnenolone $(2 \%), 11$ deoxycorticosterone $(2 \%), 11$ deoxycortisol $(2 \%), 20$ hydroxy-4-pregnane-3-one $(0 \cdot 4 \%), 3$ hydroxy-5-pregnane-20-one $(0-3 \%)$, cortisol $(<0.1 \%)$, testosterone $(<0.001 \%), \Delta-4$-androstenedione $(<0.001 \%), 17 \beta$-oestradiol $(<0.001 \%)$, and oestrone $(<0.001 \%))$ and incubated at room temperature for $30 \mathrm{~min}$. Then, $0.1 \mathrm{ml}$ of tritiated progesterone in radioimmunoassay buffer (10000 c.p.m., TRK 413, Radiochemical Centre, Amersham, UK) was added and incubated for $\mathrm{l} h$ at $37^{\circ} \mathrm{C}$. Separation was achieved using dextran-charcoal and the supernatant was counted. The intra- and interassay coefficients of variation were $<10 \%$. Sensitivity was $0.31 \mathrm{ng} / \mathrm{ml}$.

LH was measured in plasma by radioimmunoassay using antiserum (NIADDK-anti-oLH-1) and ovine LH (NIADDK-o-LH-I-3, iodinated by the chloramine method), which were kindly provided by the NIADDK (National Institute for Diabetic, Digestive and Kidney Diseases) and used as recommended. Intra-assay and interassay coefficients of variation were $<5 \%$ and $<8 \%$ respectively.

Estimation of fetal age. Fetal age was estimated from fetal mass using the Huggett \& Widdas (1951) equation, modified to take into account the period of delayed implantation (van der Merwe, 1979).

Statistical analyses. Differences between means were evaluated using Student's $t$ test, where two means are compared, and one-way analyses of variance when more than two means are compared. Data are presented as means \pm 1 s.d.

\section{Results}

\section{Female reproductive cycle and plasma progesterone concentrations}

Copulation, ovulation and fertilization occurred in April and May, and implantation was delayed until August (Fig. 1). During the period of delayed implantation, the conceptus was maintained at the bilaminar blastocyst stage and floated freely in the lumen of the right uterine horn. Normal embryogenesis ensued after implantation in August, neurulation occurred in late August, and limb buds first appeared in mid-September. There was no period of post-implantation delayed development. Parturition occurred approximately 4 months after implantation, in December. In the study area, long-fingered bats remain active and do not hibernate throughout winter, but enter prolonged periods of torpor during particularly cold spells only (Bernard \& Bester, 1989). Environmental conditions and the pattern of winter activity did not differ greatly in the 3 years of the study.

Plasma progesterone concentrations during non-pregnancy (January to March) were low $(1.54 \pm 1.00 \mathrm{ng} / \mathrm{ml} ; n=10)$ and there was a small, statistically non-significant $(P>0 \cdot 1)$ peak in May, just after fertilization $(6.22 \pm 3.48 \mathrm{ng} / \mathrm{ml} ; n=3)$. Two of the three specimens from May each had a single morula in the left oviduct and plasma progesterone concentrations of 3.59 and $4.90 \mathrm{ng} /$ $\mathrm{ml}$, respectively, and the third had a unilaminar blastocyst in the right uterine horn and $10 \cdot 16 \mathrm{ng}$ plasma progesterone/ml. Plasma progesterone concentrations during delayed implantation 
(June to August) were low $(1.67 \pm 0.58 \mathrm{ng} / \mathrm{ml} ; n=7)$ and were not significantly different from those during non-pregnancy $(P>0 \cdot 1)$. At implantation in August, plasma progesterone concentrations were low $(3.8 \pm 1.05 \mathrm{ng} / \mathrm{ml} ; n=3)$ and thereafter they increased rapidly, reaching a peak mean value of $64.82 \mathrm{ng} / \mathrm{ml}$ in late November (Fig. 1). There was an order of magnitude decrease in plasma progesterone concentrations after parturition (two lactating specimens in December) (Fig. 1).

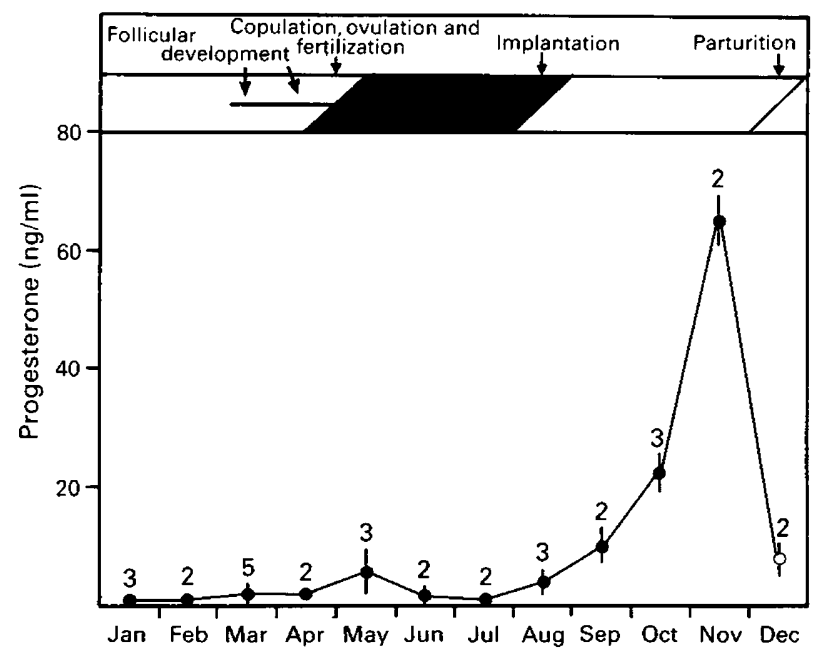

Fig. 1. Plasma progesterone concentrations (mean \pm 1 s.d.) of adult female long-fingered bats and a summary of the reproductive cycle illustrating the approximate timing of events and the period of delayed implantation ( $\square$ ). Sample size is given above each value; open symbol $(O)$ is for 2 lactating females.

Five fetuses, differing in mass and therefore estimated age, were obtained from the pregnant females collected between October and late November. In each monthly sample, specimens with the greatest fetal mass were associated with the highest maternal plasma progesterone concentrations; there was a linear relationship between estimated fetal age and maternal plasma progesterone concentrations $(y=-217 \cdot 6+1 \cdot 23 x ; r=0.955 ; P=0.004)$.

\section{Ultrastructure of the luteal cells}

The single corpus luteum occupied approximately three-quarters of, and was restricted to, the left ovary and comprised one type of secretory cell (luteal cell), vascular elements, connective tissue and fibroblasts. The luteal cells were characterized by variable amounts of smooth endoplasmic reticulum, mitochondria, lipid droplets and membrane-bound, electron-dense granules (Fig. 2).

Shortly after ovulation in May, the luteal cells were small $\left(\bar{x}\right.$ area $\left.=254 \cdot 4 \pm 22 \cdot 1 \mu \mathrm{m}^{2}\right)$ and the cytoplasm contained numerous mitochondria with tubular and lamellar cristae, and a few lipid droplets and membrane-bound, electron-dense granules (Table 1; Fig. 2a). Golgi. bodies were scarce. During delayed implantation (June to August), the luteal cells were significantly smaller than in May. There was a significant reduction in the relative volume density of the mitochondria, which now had lamellar cristae, and a significant increase in the abundance of lipid droplets (Table 1; Fig. 2b). After implantation, the luteal cells increased significantly in size, which was accompanied by significant increases in the relative volume densities of the mitochondria and membrane-bound bodies (Table 1). Lipid droplets were significantly more abundant at the beginning of this period and thereafter their relative volume density decreased (Fig. 2c). Smooth endoplasmic reticulum was much more abundant after implantation than during delayed implantation (Fig. 2). 
In the last 2 months of gestation, the luteal cells decreased in size and there were concomitant decreases in the relative volume densities of all the organelles associated with steroidogenesis (Table 1). Lysosomes were abundant for the first time and the nuclei of the luteal cells were often shrunken.

\section{Plasma LH concentrations and the abundance and activity of the LH gonadotrophs}

Plasma LH concentrations differed significantly during the year $(P<0.01)$, being low in the 2 months preceding follicular development and increasing during follicular development to reach a peak in April $(6.2 \pm 1.4 \mathrm{ng} / \mathrm{ml}$; Fig. 3). There was a significant decline $(P<0.05)$ in plasma $\mathrm{LH}$ concentration at the time of ovulation and it remained low during early delayed implantation. From July onwards, LH concentrations increased, reaching a peak in November $(5.9 \pm 1.9 \mathrm{ng} / \mathrm{ml})$ with a marked decline prior to parturition.

LH gonadotrophs occupied $4-7 \%$ of the area of the pars distalis in the months preceding follicular development and during delayed implantation; in April and during post-implantation development, they occupied $12-13 \%$ (Fig. 3). Pituitary LH- $\beta$ immunoreactivity was greatest during follicular development, with a marked decline at the time of ovulation (April/May; Fig. 3). During delayed implantation, LH- $\beta$ immunoreactivity remained low (Figs 3 \& 4a) and there was a steady increase after implantation, reaching a peak in October (Figs $3 \& 4$ b). Changes in the abundance of LH gonadotrophs, and pituitary $\mathrm{LH}-\beta$ immunoreactivity mirrored changes in plasma $\mathrm{LH}$ concentration, suggesting that, in spite of the small sample, the changes were real (Fig. 3).

\section{Discussion}

The principal differences between the two reproductive patterns reported for long-fingered bats from temperate latitudes lie in the length of the period of delayed implantation and the occurrence of a period of post-implantation delayed embryonic development. Results from the present study indicate that at $33^{\circ} \mathrm{S}$ the period of delayed implantation is about 4 months, that the period from implantation to the first appearance of limb buds is about 1 month and, consequently, that there is no period of delayed embryonic development. However, van der Merwe \& van Aarde (1989) maintain that, in the same species at $25^{\circ} \mathrm{S}$ in South Africa, a 4-month period of delayed implantation is followed by an 8 -week period of slow embryonic development. At $25^{\circ} \mathrm{S}$, ovulations occur over 1 month (van der Merwe, 1986), implantation occurs between July and September (van der Merwe, 1980), and fetuses collected in mid-September range in age from 153 to 180 days (van der Merwe \& van Aarde, 1989). Taking into account this asynchrony in the timing of reproduction, it is not possible to determine accurately the length of the period between implantation and the first appearance of limb buds, or therefore to establish whether post-implantation development is delayed. Furthermore, the duration of post-implantation development at $25^{\circ} \mathrm{S}$ (van der Merwe \& van Aarde, 1989), and at $33^{\circ} \mathrm{S}$ (present study) is about 4 months and thus differs from the reproductive cycle of long-fingered bats from Australia and Japan, in which there is a period of delayed embryonic development, and post-implantation development takes 5-6 months (Kimura \& Uchida, 1983; Crichton et al., 1989).

The hormonal control of delayed implantation has been investigated in many mammals and plasma progesterone concentrations are low (roe deer: Sempéré, 1977; badger: Bonnin et al., 1978; mink: Sundqvist et al., 1989; long-fingered bat: present study) and the corpus luteum is typically inactive during the reproductive delay (skunk: Sinha \& Mead, 1975; mink: Martinet et al., 1981; long-fingered bat: Peyre \& Herlant, 1963; Uchida et al., 1984; Crichton et al., 1989; present study). Similarly, plasma progesterone concentrations are low and the corpus luteum is suboptimally active during post-implantation delayed development in the bat (Macrotus californicus: Burns \& Easley, 1977; Crichton \& Krutzsch, 1985; Crichton et al., 1990). In long-fingered bats from 
(a)

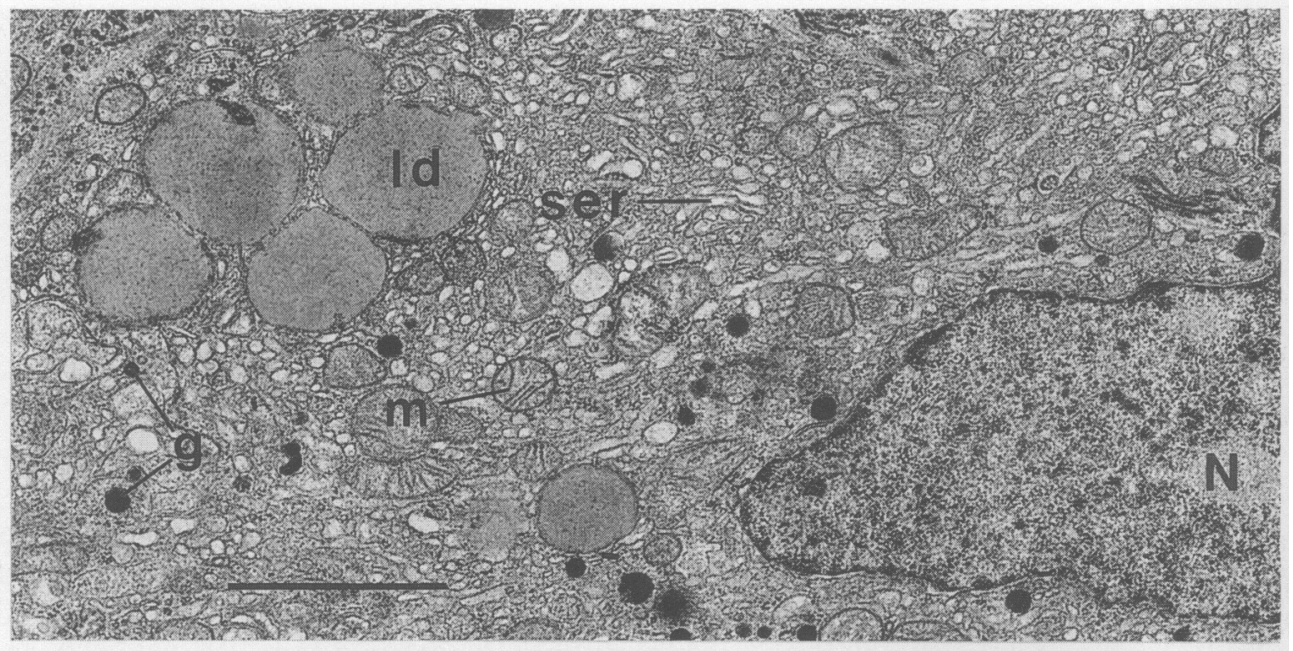

(b)

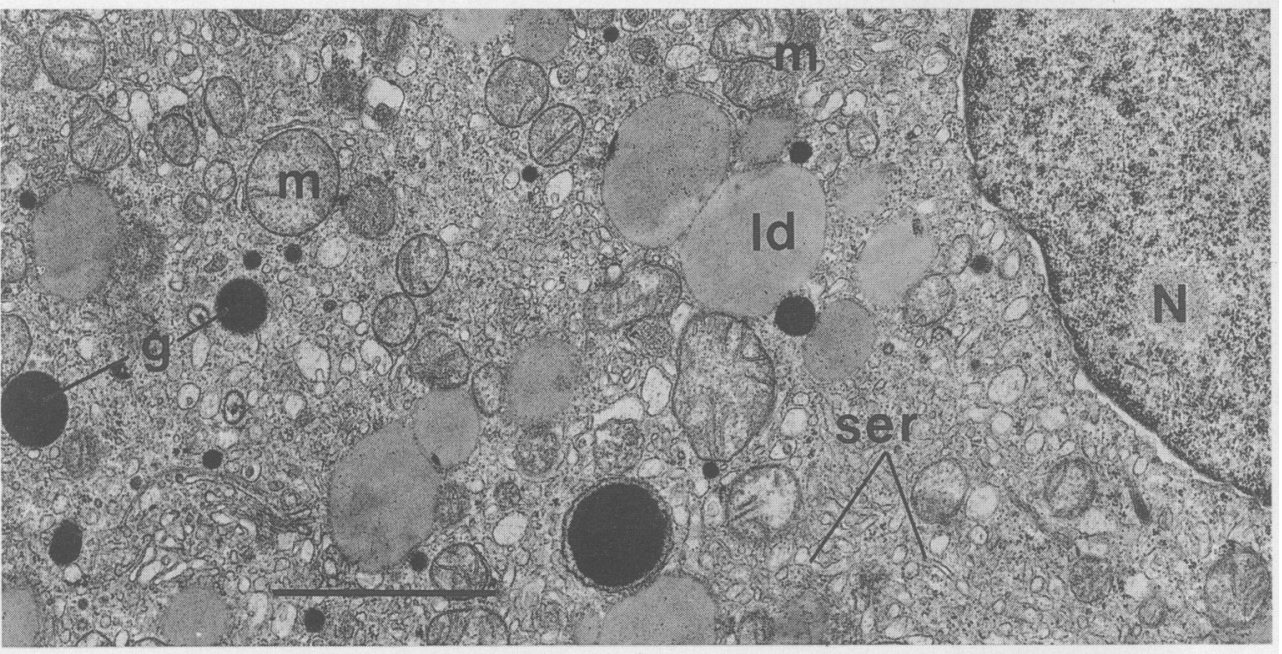

(c)

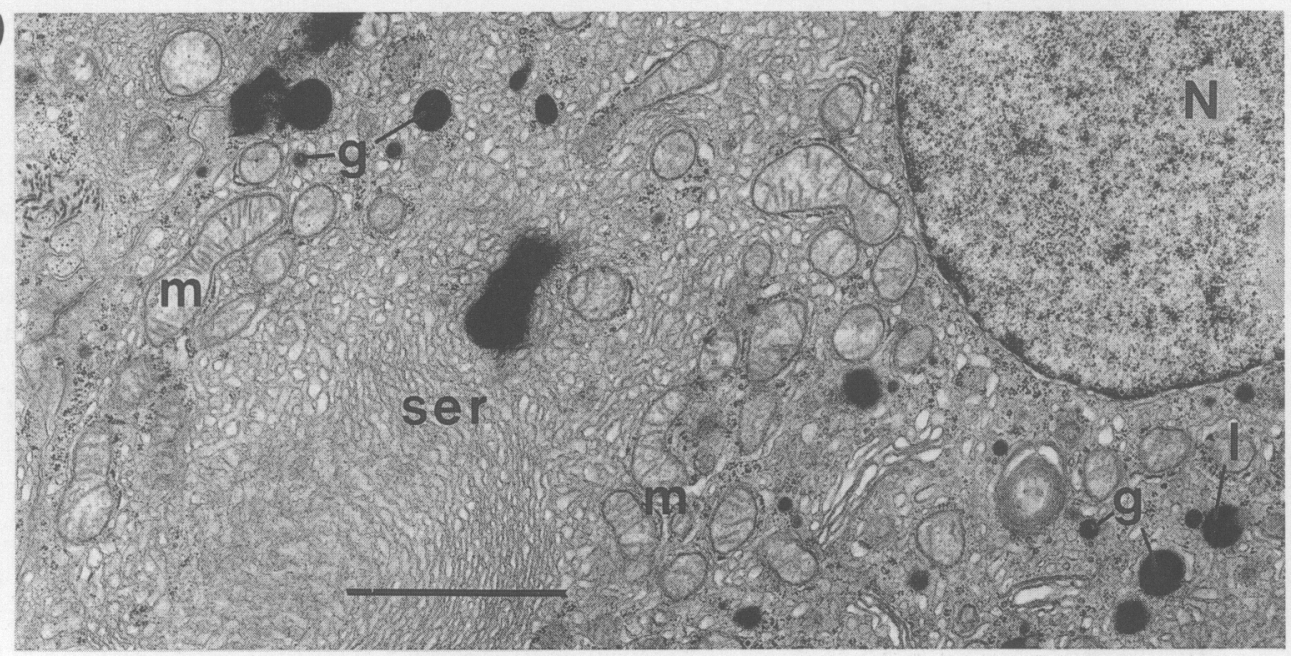


Table 1. Luteal cell size and relative volume densities of steroidogenic organelles during four stages of the gestation of the long-fingered bat

Relative volume densities ( $\%$ of cytoplasm +1 s.d.)

\begin{tabular}{|c|c|c|c|c|c|}
\hline \multirow[b]{2}{*}{ Stage of gestation } & \multirow[b]{2}{*}{$\begin{array}{l}\text { Luteal cell } \\
\text { size }\left(\mu \mathrm{m}^{2}\right)\end{array}$} & \multirow[b]{2}{*}{ Mitochondria } & & & \\
\hline & & & Lipid droplets & \multicolumn{2}{|c|}{$\begin{array}{l}\text { Electron-dense } \\
\text { membrane-bound } \\
\text { granules }\end{array}$} \\
\hline $\begin{array}{l}\text { Early gestation } \\
\text { (May) }\end{array}$ & $254 \cdot 4 \pm 22 \cdot 1^{\mathrm{a}}$ & $23 \cdot 0 \pm 1 \cdot 6^{a}$ & $1.9 \pm 0.3^{\mathrm{a}}$ & $0 \cdot 9 \pm 0 \cdot 2^{a}$ & 3 \\
\hline $\begin{array}{l}\text { Delayed implantation } \\
\text { (June-August) }\end{array}$ & $201 \cdot 7 \pm 27 \cdot 3^{b}$ & $12 \cdot 2 \pm 1 \cdot 3^{b}$ & $11 \cdot 8 \pm 1.9^{b}$ & $1 \cdot 08 \pm 0 \cdot 17^{\mathrm{a}}$ & 7 \\
\hline $\begin{array}{l}\text { Embryogenesis } \\
\text { (August-September) }\end{array}$ & $510 \cdot 0 \pm 53 \cdot 6^{\mathrm{c}}$ & $35 \cdot 3 \pm 2 \cdot 7^{\mathrm{c}}$ & $20 \cdot 2 \pm 2 \cdot 6^{c}$ & $11.4 \pm 1.5^{b}$ & 5 \\
\hline $\begin{array}{l}\text { Late gestation } \\
\quad \text { (October-November) }\end{array}$ & $337 \cdot 1 \pm 32 \cdot 1^{d}$ & $30 \cdot 5 \pm 1 \cdot 6^{d}$ & $2 \cdot 3 \pm 1 \cdot 0^{a}$ & $7 \cdot 4 \pm 3 \cdot 1^{c}$ & 2 \\
\hline ANOVA & $P<0.001$ & $P<0.001$ & $P<0.001$ & $P<0.001$ & \\
\hline
\end{tabular}

Values are means \pm s.d. for the no. of specimens indicated $(n)$.

For each column, values with a common superscript do not differ significantly $(P>0.05)$.



Fig. 3. Monthly changes in (a) plasma luteinizing hormone (LH) concentration ( $\bullet$ ) and abundance of LH gonadotrophs $(O)$ and (b) pituitary LH- $\beta$ immunoreactivity in the long-fingered bat. LH concentration is given as mean \pm 1 s.d., with sample size above each value. The index of pituitary LH- $\beta$ immunoreactivity was obtained by multiplying the volume density of secretory granules by the number of gold particles per granule; ( $\boldsymbol{E})$ delayed implantation.

Fig. 2. Electron micrographs showing the typical ultrastructure of luteal cells in female longfingered bats from (a) early (May) and (b) late (August) delayed implantation and (c) postimplantation development (October). Note the smooth endoplasmic reticulum (ser) and mitochondria $(\mathrm{m})$, which are more abundant in October; the lipid droplets (ld) present before implantation ( $\mathrm{a}$ and $\mathrm{b}$ ); and the electron-dense membrane-bound granules ( $\mathrm{g}$ ), which are most abundant in October; $1=$ lysosome; $\mathrm{N}=$ nucleus. Scale bars $=2 \cdot 0 \mu \mathrm{m}$. 
Australia and Japan, plasma progesterone concentrations are low during both delayed implantation and delayed embryonic development and increase rapidly after arousal from hibernation and the onset of normal embryogenesis (Kimura et al., 1987; Crichton et al., 1989). By contrast, at $25^{\circ} \mathrm{S}$ in South Africa, plasma progesterone concentrations are significantly increased during delayed implantation, decrease after implantation and thereafter increase to reach a peak prior to parturition (van der Merwe \& van Aarde, 1989).

The increase in plasma progesterone concentration after fertilization reported in the present study is not unusual and has been reported in the little brown bat (Myotis lucifugus: Buchanan \& Younglai, 1986) and the little mastiff bat (Mormopterus planiceps: Crichton \& Krutzsch, 1987). Furthermore, the small increase in plasma progesterone during delayed implantation in the Japanese long-fingered bat is based on five specimens collected about 2 weeks after fertilization (Kimura et al., 1987) and probably represents the increase in plasma progesterone concentrations after fertilization seen in the present study.

Some ultrastructural traits correlated with an increase in the rate of steroidogenesis are increases in cell size (Kimura \& Uchida, 1983; Hoyer et al., 1988) and abundance of organelles, such as smooth endoplasmic reticulum and mitochondria, that are involved in steroidogenesis (Zirkin et al., 1980; Lunstra et al., 1986; Kenny et al., 1989). In the present study, delayed implantation was characterized by a reduction in size of the luteal cells and abundance of mitochondria, and an increase in abundance of lipid droplets (which store precursors for steroidogenesis; Hall, 1984). These trends indicate an initial period of steroidogenesis which coincides with the postfertilization increase in plasma progesterone concentration, followed by a reduction in secretory activity during delayed implantation. The increase in the size of the luteal cells and in the abundance of mitochondria, and the decline in abundance of lipid droplets (indicating utilization of stored precursors) during September and October support the occurrence of a period of steroidogenesis that follows implantation and which is accompanied by an increase in plasma progesterone. The membrane-bound bodies, which increase in abundance after implantation, may store oxytocin, as has been reported for some ruminants and primates, where it plays a role in luteolysis (Auletta \& Flint, 1988). The decrease in size of the luteal cells in the last 2 months of gestation, the concomitant reduction in abundance of steroidogenic organelles, and the increased abundance of lysosomes and autophagic vacuoles all indicate the onset of luteolysis. In the same species from Australia, there are similar signs of luteolysis in the last 2 months of pregnancy (Crichton et al., 1989). Within the Chiroptera, data supporting placental steroidogenesis are available for long-fingered bats (Fonda \& Peyre, 1965; Peyre \& Malassine, 1969; van der Merwe $\&$ van Aarde, 1989) and the little brown bat (Currie et al., 1988), and it seems likely that in Schreibers' long-fingered bat there is a luteoplacental shift in the site of progesterone production 1-2 months before parturition.

In most mammals that use delayed implantation, implantation coincides with reactivation of the corpus luteum and increasing plasma progesterone concentrations (Stoufflet et al., 1989). Although implantation in the long-fingered bat coincides with activation of the corpus luteum (present study), plasma progesterone concentrations just after implantation remain low. In longfingered bats from Australia, implantation occurs in midwinter and there is no marked change in the status of the corpus luteum or plasma progesterone concentration until 46 weeks after implantation (Crichton et al., 1989). These data support the observation that in the ferret (Mustela putorius) a luteal protein, in association with progesterone, plays a significant role in implantation (Mead et al., 1988).

In the long-fingered bat, as in most mammals with delayed implantation, the abundance of LH gonadotrophs, pituitary LH content (or LH- $\beta$ immunoreactivity), and plasma LH concentration are low during delayed implantation (Peyre \& Herlant, 1963; Foresman \& Mead, 1974; Canivenc \& Bonnin, 1981; Mikami et al., 1988; present study). However, while LH may play a role in the maintenance of luteal function, it is not responsible for reactivating the corpus luteum at the end of delayed implantation in mink (Martinet et al., 1981; Murphy et al., 1981) or skunk (Berria et al., 


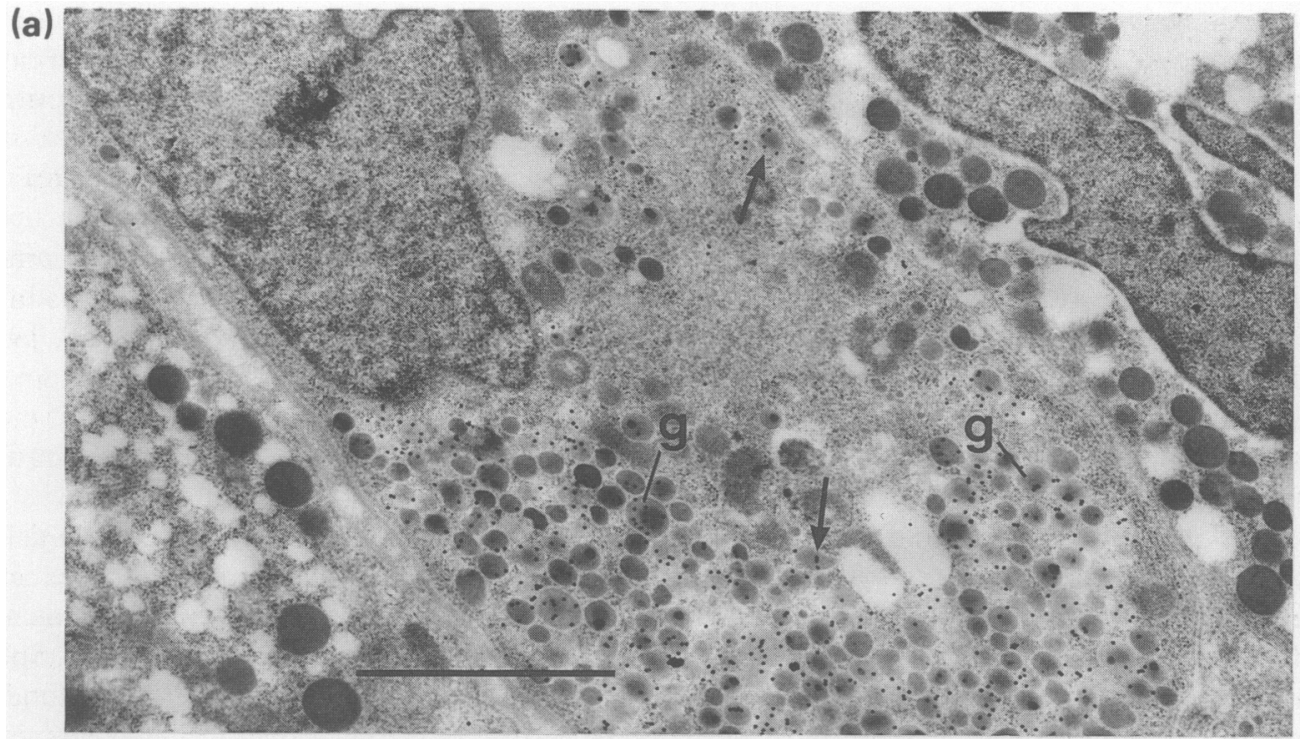

(b)

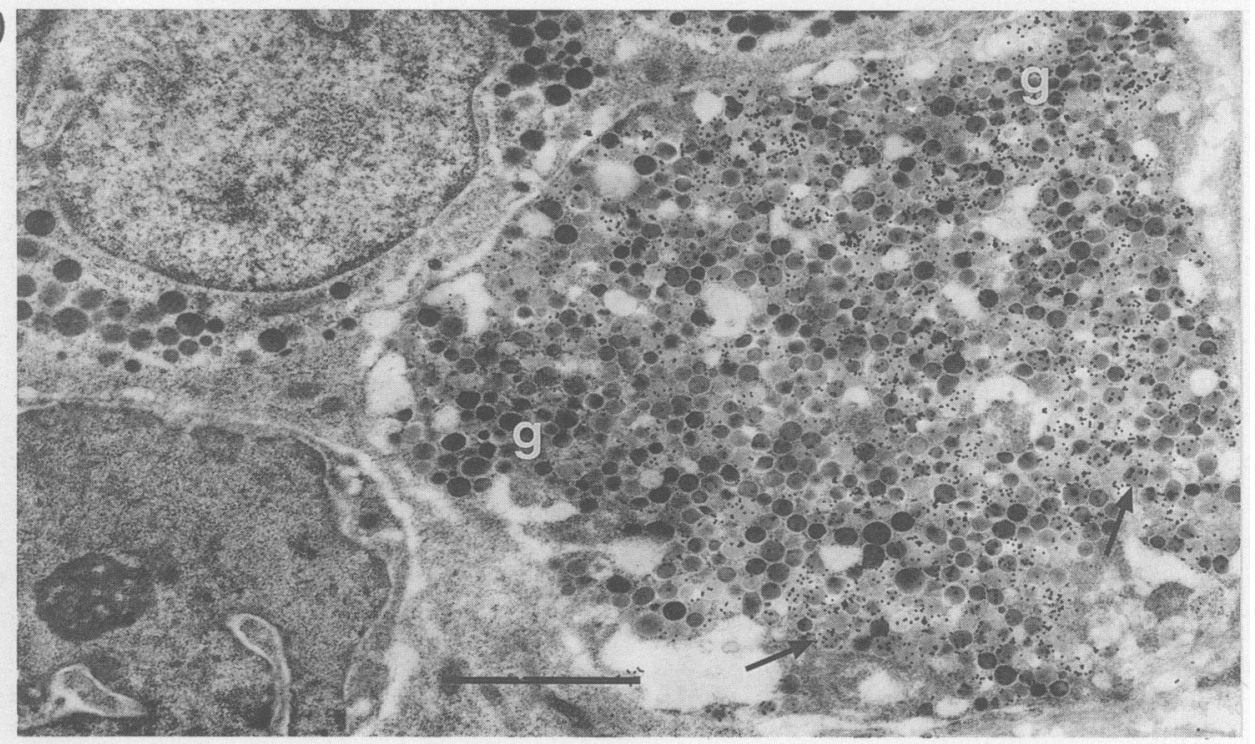

Fig. 4. Electron micrographs of immunogold-stained gonadotrophs in the long-fingered bat in (a) August and (b) October, showing a large number of secretory granules (g) and an increased number of gold particles (arrows) per granule in October. Scale bars $=2 \cdot 0 \mu \mathrm{m}$.

1989). In the long-fingered bat (present study), the abundance of LH gonadotrophs, pituitary LH- $\beta$ immunoreactivity and plasma LH concentration increase from July to October/November and, while this may indicate that LH is part of a luteotrophic complex, it gives no clear indication of whether $\mathrm{LH}$ plays a role in reactivating the corpus luteum.

The increase in plasma LH concentrations during follicular development coincides with maximum abundance of LH gonadotrophs and peak pituitary LH- $\beta$ immunoreactivity; similar trends have been reported in other bats (Richardson, 1979; Anthony \& Gustafson, 1984; Canney \& Butler, 1987) and mammals in general (see Gore-Langton \& Armstrong, 1988 for review). 
In long-fingered bats, it has been suggested that torpor may be responsible for suppression of luteal activity and consequently developmental delay (Uchida et al., 1984; Crichton et al., 1989). In small carnivores with delayed implantation, prolactin is responsible for reactivating the corpus luteum (Murphy et al., 1981; Sundqvist et al., 1989) and, since production and secretion of prolactin increase with increasing day length, it is photoperiod rather than temperature that controls delayed implantation. It is intriguing that, in long-fingered bats, implantation occurs under conditions of increasing day length (see Racey, 1982 for review). Furthermore, preliminary data indicate that pituitary prolactin immunoreactivity in the long-fingered bat is low during delayed implantation and increases significantly at implantation (R. T. F. Bernard \& C. Bojarski, unpublished data). It seems possible that the mechanism elucidated for the control of delayed implantation in small carnivores may function in long-fingered bats.

Development of the corpus luteum after implantation may be inhibited by low ambient temperatures and torpor; this would explain the occurrence of post implantation luteal inactivity and delayed embryonic development in long-fingered bats from Japan and Australia. Such a system could be advantageous in an environment in which the duration of winter is unpredictable, since, although the timing of implantation would be fixed by photoperiod, ambient conditions after implantation would determine the length of the period of delayed embryonic development. Such a system should result in variations in gestation length and, indeed, two studies of long-fingered bats at a single locality in Australia have reported births occurring in October and December (Hamilton-Smith, 1972; Richardson, 1979).

We thank Rhodes University, the University of Cape Town, the FRD and MRC for financial assistance, Professor R. van Aarde for useful discussion, and A. van Zyl and the Staff of the electron microscopy unit at Rhodes University for technical assistance.

\section{References}

Anthony, E.L.P. \& Gustafson, A.W. (1984) Seasonal variation in pituitary $\mathrm{LH}$ gonadotropes of the hibernating bat Myotis lucifugus: an immunohistochemical study. Am. J. Anat. 170, 101-115.

Auletta, F.J. \& Flint, A.P. (1988) Mechanisms controlling corpus luteum function in sheep, cows, nonhuman primates, and woman, especially in relation to the time of luteolysis. Endocrine Rev. 9, 88-105.

Berria, M., Joseph, M.M. \& Mead, R.A. (1989) Role of prolactin and luteinizing hormone in regulating timing of implantation in the spotted skunk. Biol. Reprod. 40, 232-238.

Bernard, R.T.F. (1980) Reproductive cycles of Miniopterus schreibersii natalensis (A. Smith, 1834) and Miniopterus fraterculus Thomas and Schwann, 1906. Ann. Transv. Mus. 32, 55-64.

Bernard, R.T.F. (1989) The adaptive significance of reproductive delay phenomena in some South African Microchiroptera. Mammal Rev. 19, 27-34.

Bernard, R.T.F. \& Bester, G.J. (1989) Roost selection by the long-fingered bat, Miniopterus schreibersii is influenced by reproductive condition and roost microclimate and structure. S. Afr. J. Sci. 84, $921-922$.

Bonnin, M., Canivenc, R. \& Ribes, C.L. (1978) Plasma progesterone levels during delayed implantation in the European badger (Meles meles). J. Reprod. Fert. 52, 55-58.

Buchanan, G.D. \& Younglai, E.V. (1986) Plasma progesterone levels during pregnancy in the little brown bat, Myotis lucifugus (Vespertilionidae). Biol. Reprod. 34, 878-884.
Burns, J.M. \& Easley, R.G. (1977) Hormonal control of delayed development in the Californian leaf-nosed bat, Macrotus californicus. III. Changes in plasma progesterone during pregnancy. Gen. Comp. Endocr. 32, $163-166$.

Canivenc, R. \& Bonnin, M. (1981) Environmental control of delayed implantation in the European badger (Meles meles). J. Reprod. Fert., Suppl. 29, $25-33$.

Canney, D.H. \& Butler, W.R. (1987) Plasma and pituitary luteinizing hormone concentrations during delayed ovulation in the little brown bat, Myotis lucifugus. Biol. Reprod., Suppl. 36, 121, abstr.

Chegini, N. \& Rao, Ch.V. (1988) Increase of nuclear bodies in bovine luteal cells after treatment with human chorionic gonadotropin. Biol. Reprod. 38, 453-461.

Courrier, R. (1927) Etude sur la déterminisme des caractères sexuel secondaires chez quelques mammifères a l'activité testiculaire périodique. Arch. Biol. 37, 173-334.

Crichton, E.G. \& Krutzsch, P.H. (1985) Reproductive biology of the female leaf-nosed bat, Macrotus californicus, in southwestern United States. I. A morphometric analysis of the annual ovarian cycle. Am. J. Anat. 173, 69-87.

Crichton, E.G. \& Krutzsch, P.H. (1987) Reproductive biology of the female little mastiff bat, Mormopterus planiceps (Chiroptera: Molossidae) in southeast Australia. Am. J. Anat. 178, 369-386.

Crichton, E.G., Seamark, R.F. \& Krutzsch, P.H. (1989) The status of the corpus luteum during pregnancy in 
Miniopterus schreibersii (Chiroptera: Vespertilionidae) with emphasis on its role in developmental delay. Cell Tissue Res. 258, 183-201.

Crichton, E.G., Hoyer, P.B. \& Krutzsch, P.H. (1990) Cellular composition and steroidogenic capacity of the ovary of Macrotus californicus (Chiroptera: Phyllostomatidae) during and after delayed embryonic development. Cell Tissue Res. 260, 355-366.

Cross, R.H.M. (1989) A reliable epoxy resin mixture and its application in routine biological transmission electron microscopy. Micron and Microscopica Acta 20, $1-7$.

Crombie, P.R., Burton, R.D. \& Ackland, N. (1971) The ultrastructure of the corpus luteum of the guinea-pig. Z. Zellforsch. 115, 473-493.

Currie, W.B., Blake, M. \& Wimsatt, W.A. (1988) Fetal development, and placental and maternal plasma progesterone in the little brown bat (Myotis lucifugus). $J$. Reprod. Fert. 82, 401- 407.

Fonda, E. \& Peyre, A. (1965) Localization de la $\alpha 5-3$ hydroxystéroidodes-hydrogénase dans la placenta de minioptère au cours de la gestation. C. r. hebd. Séanc. Acad. Sci., Paris 261, 2963-2969.

Foresman, K.R. \& Mead, R.A. (1974) Patterns of luteinizing hormone secretion during delayed implantation in the spotted skunk (Spilogale putorius). Biol. Reprod. 11, 474-480.

Gore-Langton, R.E. \& Armstrong, D.T. (1988) Follicular steroidogenesis and its control. In The Physiology of Reproduction, pp. 331-386. Eds E. Knobil \& J. Neil. Raven Press, New York.

Hall, P.F. (1984) Cellular organization for steroidogenesis. Int. Rev. Cytol. 86, 53-94.

Hamilton-Smith, E. (1972) The bat population of the Naracoorte Caves area. Proc. Nat. Conf. Aust. Speleol. Fed. 8, 66-75.

Hoyer, P.B., Kong, W., Crichton, E.G., Bevan, L. \& Krutzsch, P.H. (1988) Steroidogenic capacity and ultrastructural morphology of cultured ovine luteal cells. Biol. Reprod. 38, 909-920.

Huggett, A. St G. \& Widdas, W.F. (1951) The relationship between foetal weight and conception age. $J$. Physiol. 114, 306-317.

Kenny, N., Farin, C.E. \& Niswender, G.D. (1989) Morphometric quantification of mitochondria in the two steroidogenic ovine luteal cell types. Biol. Reprod. 40, 191-196.

Kimura, K. \& Uchida, T.A. (1983) Ultrastructural observations of delayed implantation in the Japanese longfingered bat, Miniopterus schreibersii fuliginosus. $J$. Reprod. Fert. 69, 187-193.

Kimura, K., Takeda, A. \& Uchida, T.A. (1987) Changes in progesterone concentration in the Japanese longfingered bat, Miniopterus schreibersii fuliginosus. J. Reprod. Fert. 80, 59-63.

Lunstra, D.D., Ford, J.J., Christensen, R.K. \& Allrich, R.D. (1986) Changes in Leydig cell ultrastructure and function during pubertal development in the boar. Biol. Reprod. 34, 145-158.

Martinet, L., Allais, C. \& Allain, D. (1981) Role of prolactin and $\mathrm{LH}$ in luteal function and blastocyst growth in mink (Mustela vison). J. Reprod. Fert., Suppl. 29, 119-130.

Mead, R.A., Joseph, M.M., Neirinckx, S. \& Berria, M. (1988) Partial characterization of a luteal factor that induces implantation in the ferret. Biol. Reprod. 38, $798-803$.

Mikami, S., Chiba, S., Hojo, H., Taniguchi, K., Kubokawa, K. \& Ishii, S. (1988) Immunocytochemical studies on the pituitary pars distalis of the Japanese long-fingered bat, Miniopterus schreibersii fuliginosus. Cell Tissue Res. 251, 291-299.

Murphy, B.D., Concannon, P.W., Travis, H.F. \& Hansel, W. (1981) Prolactin: the hypophyseal factor that terminates embryonic diapause in mink. Biol. Reprod. 25, 487-491.

Mutere, F.A. (1967) The breeding biology of equatorial vertebrates: reproduction in the fruit bat, Eidolon helvum, at latitudes $0^{\circ} 20^{\prime} \mathrm{N}$. J. Zool., Lond. 153, 153-161.

Peyre, A. \& Herlant, M. (1963) Ovo-implantation différée et corrélations hypophyso-génitales chez la femelle du minioptère (Miniopterus schreibersii B). C. r. hebd. Séanc. Acad. Sci., Paris D 257, 524-526.

Peyre, A. \& Malassine, A. (1969) L'équipment stéroidodeshydrogénasique et la fonction endocrine du placenta de minioptère (chiroptère). C.R. Soc. Biol., Paris 162, $914-917$.

Posthuma, G., Slot, S.W. \& Geuze, H.J. (1987) Usefulness of the immunogold technique in quantitation of a soluble protein in ulta-thin sections. J. Histochem. Cytochem. 35, 405-410.

Racey, P.A. (1982) Ecology of bat reproduction. In The Ecology of Bats, pp. 57-104. Ed. T. H. Kunz. Plenum Press, New York.

Ramakrishna, P.A. \& Rao, K.V.B. (1977) Reproductive adaptations in the Indian rhinolophid bat Rhinolophus rouxi (Temminck). Curr. Sci. 46, 270-271.

Renfree, M.B. \& Calaby, J.H. (1981) Background to delayed implantation and embryonic diapause. $J$. Reprod. Fert., Suppl. 29, 1-9.

Richardson, B.A. (1979) The anterior pituitary and reproduction in bats. $J$. Reprod. Fert. 56, 379-386.

Sempéré, A. (1977) Plasma progesterone levels in the roe deer Capreolus capreolus. J. Reprod. Fert. 50, 365-366.

Sinha, A.A. \& Mead, R.A. (1975) Ultrastructural changes in the granulosa lutein cells and progesterone levels during preimplantation, implantation, and early placentation in the western spotted skunk. Cell Tissue Res. 164, 179-192.

Stoufflet, I., Mondain-Monval, M., Simon, P. \& Martinet, L. (1989) Patterns of plasma progesterone, androgen and oestrogen concentrations and in-vitro ovarian steroidogenesis during embryonic diapause and implantation in the mink (Mustela vison). J. Reprod. Fert. 87, 209-221.

Sundqvist, C., Amador, A.G. \& Bartke, A. (1989) Reproduction and fertility in the mink (Mustela vison). J. Reprod. Fert. 85, 413-441.

Uchida, T.A., Inoue, C. \& Kimura, K. (1984) Effects of elevated temperature on embryonic development and corpus luteum activity in the Japanese long-fingered bat, Miniopterus schreibersii fuliginosus. J. Reprod. Fert. 71, 439-444.

van der Merwe, M. (1979) Foetal growth curves and seasonal breeding in the Natal clinging bat, Miniopterus schreibersii natalensis. S. Afr. J. Zool. 14, 17-21. 
van der Merwe, M. (1980) Delayed implantation in the Natal clinging bat Miniopterus schreibersii natalensis (A. Smith, 1834). In Proc. 5th Int. Bat Res. Conf., Albuquerque, pp. 113-123. Eds D. E. Wilson \& A. L. Garner. Lubbock, Texas.

van der Merwe, M. \& van Aarde, R.J. (1989) Plasma progesterone concentrations in the female Natal clinging bat (Miniopterus schreibersii natalensis). J. Reprod. Fert. 87, 665-669.

Weibel, E.R. \& Bolender, R.P. (1973) Stereological techniques for electron microscopic morphometry. In
Principles and Techniques for Electron Microscopy, vol. 3, pp. 237-296. Ed. M. A. Hayat. Van NostrandReinhold, New York.

Zirkin, B.R., Ewing, L.L., Kromann, N. \& Cochran, R.C. (1980) Testosterone secretion by rat, rabbit, guinea pig, dog and hamster testes perfused in vitro: correlations with Leydig cell ultrastructure. Endocrinology $107,1867-1874$.

Received 22 June 1990 